\title{
Kepemimpinan Kepala Sekolah dalam Menghadapi Era Revolusi Industri 4.0: Perspektif Sosiologi Pendidikan
}

\author{
Aulia Nursyifa ${ }^{\mathrm{a}, 1}$ * \\ aProgram Studi Pendidikan Pancasila dan Kewarganegaraan, \\ Fakultas Keguruan dan Ilmu Pendidikan, Universitas Pamulang, Tangerang Selatan \\ ${ }^{1}$ aulianursyifa@unpam.ac.id \\ *korespondensi penulis
}

Naskah diterima: 25-08-19, direvisi: 17-09-19, disetujui: 27-09-19

DOI: http://dx.doi.org/10.32493/jpkn.v6i2.y2019.p143-154

\begin{abstract}
Abstrak
Pendidikan di era revolusi industri 4.0 bertransformasi mengalami berbagai perubahan, salah satunya gaya kepemimpinan kepala sekolah ditutut untuk disesuaikan dengan tuntutan era revolusi industri 4.0. Tujuan penelitian ini yaitu untuk mengetahui gaya kepemimpinan kepala sekolah dalam menghadapi era revolusi industry 4.0 dalam perspektif Sosiologi Pendidikan. Penelitian ini menggunakan metode penelitian kualitatif dengan pendekatan fenomenologi. Teknik pengumpulan data menggunakan observasi, wawancara, dan dokumentasi penelitian. Sedangkan narasumber penelitian yaitu berjumlah 10 kepala sekolah dan 1 pengawas di Kabupaten Tangerang. Hasil penelitian menunjukkan bahwa gaya kepemimpinan kepala sekolah yang tranformasi yang demokratis mengikuti perubahan, berbagai pengetahuan serta keterampilan kepala sekolah di era revolusi industry 4.0 perlu untuk diperkuat terutama dalam keterampilan menggunakan teknologi dan kompetensi kewirausahaan.
\end{abstract}

Kata-kata kunci: kepemimpinan kepala sekolah; era revolusi industri 4.0; sosiologi pendidikan

\section{Abstract}

Education in the Revolution of the 4.0 industry has undergone a variety of changes, one of which is the leadership style of the headmaster to be adjusted to the demands of the era of the Industrial Revolution 4.0. The purpose of this research is to know the leadership style of the headmaster in the face of the 4.0 industry revolution in the sociology of education. This research uses qualitative research methods with a phenomenological approach. Data collection techniques using observation, interviews, and research documentation. Meanwhile, there are 10 principals and 1 supervisor in Tangerang Regency. The results showed that the leadership style of the school headmaster that was a democratic transformation following the change, the various knowledge and skills of the headmaster in the era of Revolution 4.0 industry need to be strengthened especially in the skills Technology and entrepreneurship competence.

Keywords: leadership of the headmaster; era of industrial revolution 4.0; sociology of education 


\section{Pendahuluan}

Era revolusi industri 4.0 menjadi suatu tantangan bagi dunia pendidikan dalam melakukan transformasi untuk dapat menyesuaikan dengan kemajuan zaman. Keberadaan era revolusi industri 4.0 ditandai dengan kemajuan dibidang mobile dan internet, smartphone, komputerisasi data, kecerdasan buatan, dan robotisasi (Schwab: 2016). Keberadaan berbagai perubahan sosial tersebut ikut mempengaruhi sistem pendidikan. Menurut Durkheim (dalam Hidayat. 2014) lembaga pendidikan merupakan miniatur dari kehidupan masyarakat, sehingga pendidikan berupaya untuk memenuhi berbagai tuntutan masyarakat. Pada era disruptif lembaga pendidikan tidak hanya dituntut untuk menguasai kemajuan ilmu pengetahuan dan teknologi, namun pendidikan harus mampu mencetak sumber daya manusia yang berkualitas yang dapat bersaing dalam tataran lokal, nasional, maupun global.

Dalam upaya meningkatkan kualitas pendidikan di era revolusi industri 4.0, salah satu komponen sangat penting untuk merealisasikannya yaitu terletak pada peran penting kepemimpinan kepala sekolah dalam lembaga pendidikan. Menurut Soekanto (2010: 250) kepemimpinan (leadership) merupakan kemampuan untuk mempengaruhi orang lain sehingga orang dapat bertingkahlaku sesuai apa yang dikehendaki pemimpinnya. Menurut Haris (2013: 16) kepemimpinan kepala sekolah merupakan pemimpin yang memiliki peran membimbing, mendorong, mengarahkan, menggerakkan: guru, siswa, staf sekolah, dan berbagai pihak terkait dalam lembaga pendidikan sebagai upaya mewujudkan tujuan pendidikan. Sebagaimana yang telah diatur dalam Undang-Undang Nomor 20 Tahun 2003 tentang Sistem Pendidikan Nasional: "pendidikan bertujuan untuk mencerdaskan kehidupan bangsa sebagai upaya mengembangkan potensi peserta didik beriman dan bertakwa, berakhlak mulia, sehat, sehat, berilmu, cakap, mandiri, kreatif, serta menjadi warga negara demokratis dan bertanggung jawab" (Kemendikbud, 2003). Dalam rangka memenuhi tujuan pendidikan tersebut, dibutuhkan kepemimpinan kepala sekolah yang profesional dibuktikan dengan kompetensi yang dimilikinya.

Berdasarkan Permendikbud No 15 Tahun 2018 pasal 1 ayat 2 tentang Pemenuhan Beban Kerja Guru, Kepala Sekolah, dan Pengawas Sekolah ditegaskan bahwa: kepala sekolah adalah guru yang bertugas memimpin dan mengelola sekolah diberbagai jenjang pendidikan (Kemendikbud, 2018). Guru dapat memiliki tugas sebagai kepala sekolah asal memenuhi syarat menjadi kepala sekolah.

Sebagai upaya untuk meningkatkan kualitas pendidikan maka dimulai dari pemimpinnya. Menurut Mulyasa (2007) kepala sekolah merupakan komponen yang penting dalam pendidikan, memiliki peran dalam meningkatkan kualitas pendidikan. Kepemimpinan kepala sekolah menjadi penentu berbagai 
aturan maupun kebijakan terhadap semua warga sekolah.

Menjadi kepala sekolah yang profesional dituntut memiliki berbagai kompetensi, sebagaimana yang diatur dalam Peraturan Menteri Pendidikan Nasional Nomor 13 Tahun 2007 tentang Standar Kepala Sekolah, bahwa kepala sekolah memiliki kompetensi- kompetensi yaitu: kepribadian, supervisi, manajerial, kewirausahaan, dan kompetensi sosial (Menteri Pendidikan, 2007).

Gaya kepemimpin kepala sekolah menurut Damsar dalam buku Sosiologi Pendidikan (2012:105) yaitu kepemimpinan autokratik, laisser faire, dan demokratik. Sedangkan menurut Haris (2013) gaya kepemimpinan kepala sekolah dibagi menjadi kepemimpinan demokratis, otoriter, kharismatik (charismatic leadership), kepemimpinan kebapakkan (paternalistic leadership), kepemimpinan ahli (expert leadership, kepemimpinan yang bebas (laissez faire leadership).

Berbagai gaya kepemimpinan kepala sekolah yang beragam tersebut memiliki kelebihan dan kekurangan masingmasing, namun yang harus diperhatikan ialah implementasi gaya kepemimpinan kepala sekolah harus disesuaikan dengan keadaan yang terjadi pada lembaga pendidikan saat ini. Setiap kepala sekolah diharapkan memiliki gaya kepemimpinan yang ideal disesuaikan dengan kondisi serta tuntutan zaman.

Permasalahannya yang terjadi tidak semua kepala sekolah memiliki kemampuan untuk dapat menyesuaikan diri dengan tuntutan perubahan, ditambah lagi dengan kurangnya pengetahuan kepala sekolah terhadap tranformasi kepemimpinan kepala sekolah di abad 21.

Kepemimpinan era revolusi industri 4.0 ditandai dengan perkembangan teknologi dalam kepemimpinan pada lembaga pendidikan. Sebagaimana hasil observasi yang dilakukan peneliti ditemukan permasalahan kepala sekolah yang tidak memiliki kemampuan dalam menggunakan teknologi dalam wawancara dengan narasumber:

"Saat ini kepemimpinan kepala sekolah harus mampu dalam bidang teknologi, apalagi dengan adanya berbagai sistem pendidikan yang sudah berbasis teknologi, permasalahannya adalah saya kurang mampu dalam menggunakan komputer. Di sekolah saya terdapat komputer hanya berjumlah 3 buah untuk digunakan oleh pihak administrasi sekolah saja " (Wawancara dengan narasumber $\mathrm{SH}$, pada tanggal 1 Agustus 2019).

Masalah lainnya yaitu kurangnya kompetensi sebagai kepala sekolah yang professional sehingga menyebabkan terjadinya berbagai permasalahan di sekolah, sebagaimana hasil wawancara dengan narasumber sebagai berikut:

"Permasalahan yang terjadi dalam kepemimpinan kepala sekolah berasal dari internal yaitu pendidik dan tenaga kependidikan yang sulit diatur, guru yang tidak disiplin. Sedangkan masalah eksternal yaitu berkait dengan warga sekitar sekolah seperti protes warga sekitar sekolah yang terganggu karena suara dari kegiatan siswa di sekolah, warga yang menggunakan lahan sekolah 
untuk keperluan pribadi, serta konflik dengan wali murid" (Wawancara dengan narasumber SH, HA, pada tanggal 10 Agustus 2019).

Penelitian terkait dengan kepemimpinan kepala sekolah dalam menghadapi perubahan zaman, pernah diteliti oleh berbagai hasil penelitian. Berdasarkan hasil penelitian Yulizar \& Farida (2019) menunjukkan bahwa kepemimpinan kepala sekolah dalam era disrupsi berkontribusi terhadap mutu pendidikan, kemampuan kepala sekolah dalam melakukan pengembangan diri agar mampu menjalankan berbagai fungsi manajerial dan kepemimpinan dalam lembaga pendidikan.

Berdasarkan hasil kajian Mukhlasin (2019) menunjukkan bahwa kepemimpinan pendidikan di era revolusi industri 4.0 perlu mempersiapkan beretika, penguasaan teknologi, dan penguasaan target atau sasaran dalam kebijakan pendidikan sebagai garda terdepan dalam perubahan masyarakat.

Penelitian ini bertujuan untuk mengetahui gaya kepemimpinan kepala sekolah dalam menghadapi era revolusi industry 4.0 yang dikaji dalam perspektif Sosiologi Pendidikan. Manfaat dari penelitian ini dapat menjadi sebuah gambaran bagi kepala sekolah untuk dapat mempersiapkan diri menjadi agen perubahan, dengan gaya kepemimpinan yang disesuaikan dengan era revolusi industry 4.0 .

\section{Metode}

Metode penelitian yang digunakan dalam artikel ini yaitu penelitian kualitatif dengan pendekatan fenomenologi, peneliti menganalisis fenomena perubahan yang terjadi dalam dunia pendidikan, sehingga memaksa kepala sekolah untuk beradaptasi dengan perubahan tuntutan dunia pendidikan di era revolusi industri 4.0 .

Narasumber dalam penelitian ini berjumlah 11 orang terdiri dari 10 informan kunci yaitu Kepala Sekolah di Kabupaten Tangerang. Sedangkan informan pendukung yaitu 1 orang pengawas dari Dinas Pendidikan Kabupaten Tangerang. Adapun teknik pengambilan data dilakukan dengan cara observasi, wawancara, dan dokumentasi. Semua data terkait kepemimpinan kepala sekolah dikumpulkan menjadi satu dan dianalisis secara deskripsi. Sebagaimana yang disampaikan oleh Miles dan Huberman (dalam Silalahi, 2010: 339) "kegiatan analisis kualitatif terdiri dari tiga alur yaitu reduksi data, penyajian data, dan penarikan kesimpulan atau verifikasi". Analisis data dilakukan secara bersamaan selama pengumpulan data berlangsung sampai sesudah pengumpulan data. Berdasarkan analisis kualitatif peneliti dapat menarik hasil penelitian berdasarkan data yang ada terkait dengan kepemimpinan kepala sekolah dalam menghadapi era revolusi industri 4.0.

\section{Hasil dan Pembahasan}

Berdasarkan temuan penelitian menunjukkan bahwa gaya kepemimpinan kepala sekolah sangat beragam tergantung kepada pribadi masing-masing kepala sekolah dalam memimpin lembaganya. 
Terdapat kepala sekolah yang sangat otoriter kepada bawahannya. Berikut transkrip wawancara dengan narasumber:

"Kepemimpinan saya sangat tegas dikarenakan guru jika tidak diberikan ketegasan maka dia tidak akan disiplin, semua guru taat pada perintah saya sebagai kepala sekolah dan terbukti hasil pekerjaan dilakukan dengan baik" (Wawancara dengan narasumber JK, pada tanggal 21 Agustus 2019).

Berdasarkan hasil kutipan wawancara tersebut, menunjukkan bahwa kepemimpinan yang dilakukan oleh narasumber merupakan gaya kepemimpinan yang otoriter. Gaya kepemimpinan kepala sekolah yang otoriter cenderung untuk menggunakan kekuasaannya. Kepemimpinan yang otoriter dapat dikaji dalam teori Karl Marx mengenai konflik, melihat kepemimpinan otoriter akan memiliki kekuasaan yang mutlak berada ditangannya, sehingga hal tersebut sangat rentan menimbulkan konflik (Narwoko \& Suyanto, 2014: 175). Kepala sekolah otoriter sangat mendominasi kepemimpinannya, tegas, pemimpin dengan gaya ini mengontrol secara ketat kinerja dari bawahannya. Kepala sekolah yang bersifat otoriter tidak memberikan ruang bagi guru, staf sekolah, serta seluruh warga sekolah untuk mengemukakan pendapat sehingga mereka tidak diikutsertakan dalam mengambil keputusan. Pada akhirnya dapat menambah masalah di sekolah seperti kebijakan sekolah yang tidak tepat karena tidak dimusyawarahkan, adanya pihak-pihak yang dirugikan atau didiskriminasikan, karena kekuasaan kepala sekolah yang sangat tinggi maka beresiko terjadi penyimpangan korupsi dana sekolah.

Gaya kepemimpinan kharismatik bercirikan kepada kepribadian dari pemimpin yang istimewa memiliki kewibawaan dan daya tarik sehingga dipatuhi oleh bawahannya, pemimpin yang memiliki kekuasaan yang kuat serta dipercaya bawahannya, pemimpin yang kharismatik memiliki kemampuan mempengaruhi bawahannya dengan gaya kepemimpinannya. Berdasarkan penelitian, gaya kepemimpinan kharismatik jarang ditemukan karena keistimewaan tersebut tidak bisa dimiliki oleh sembarangan orang.

Adapun gaya kepemimpinan kebapakan merupakan gaya pemimpin yang bersifat mengayomi, melindungi, serta menolong bawahannya. Seseorang pemimpin paternalistis akan selalu menganggap bawahannya sebagai manusia yang tidak dewasa, oleh karena itu pigur kepala sekolah kebapakkan ini selalu ingin didengar serta mengetahui segalanya, sehingga jarang memberikan kesempatan kepada bawahannya dalam memberikan berbagai perubahan, inovasi atau kreasi.

Gaya kepemimpinan ahli merupakan kepemimpinan yang berdasarkan keahlian atau keterampilan yang dimiliki, pemimpin yang profesional diperoleh melalui jenjang pendidikan maupun pengalaman. Jika dilihat dari lamanya pengalaman narasumber dalam menjabat sebagai kepala sekolah hanya beberapa orang saja yang lama menjabat sebagai kepala sekolah, rata-rata menjadi kepala sekolah selama 3-10 tahun dan 
pendidikan rata-rata mendapat gelar Sarjana.

Gaya kepemimpinan laisser faire merupakan gaya kepemimpinan tidak peduli, ruang bertukar pendapat tidak diperlukan, guru dan siswa bebas melakukan apa saja untuk dilakukan. Peneliti menemukan kepala sekolah dengan gaya kepemimpinan yang memberikan kebebasan. Hal tersebut dapat dilihat dari rasa ketidakpedulian kepala sekolah dalam berbagai kegiatan sekolah, memberikan kebebesan penuh bagi guru maupun staf tanpa adanya kontrol, tidak pernah melakukan supervisi, kepala sekolah jarang datang ke sekolah sehingga kedisiplin yang kurang membuat banyak permasalahan di sekolah.

Temuan di lapangan terdapat kepala sekolah yang memiliki gaya kepemimpinan demokratis. Gaya kepemimpinan kepala sekolah yang demokratis bercirikan adanya ruang untuk bertukar pendapat sehingga segala permasalahan diselesaikan secara musyawarah kepada guru, siswa, komite sekolah, wali murid, maupun masyarakat di area sekolah. Hal ini selaras dengan pendapat Nasution (2009: 99) pada umumnya para guru di sekolah menginginkan kepala sekolah yang demokratis sehingga dapat mengambil keputusan dengan jalan musyawarah. Berikut ini dokumentasi kegiatan kepala sekolah demokratis.

Musyawarah memberikan banyak peluang partisipasi bagi seluruh warga sekolah untuk menyalurkan berbagai aspirasi, kritik, dan saran yang dapat membangun bagi kemajuan sekolah. Kepala sekolah demokratis senantiasa merangkul dan mengayomi bawahannya tanpa membeda-bedakan satu dengan yang lainnya. Kepala sekolah demokratis dapat menyelesaikan berbagai permasalahan yang terjadi di sekolah dengan bijaksana dan diputuskan bersama-sama.

Berbagai kepemimpinan tersebut harus disesuaikan dengan kondisi tuntutan masyarakat saat ini. Kepemimpinan ideal lahir dari kompetensi yang dimiliki oleh kepala sekolah dalam memimpin sekolahnya. Kompetensi kepala sekolah telah termaktub dalam Peraturan Menteri Pendidikan Nasional Nomor 13 Tahun 2007 tentang Standar Kepala Sekolah, bahwa kepala sekolah memiliki kompetensi- kompetensi yaitu: kepribadian, supervisi, manajerial, kewirausahaan, dan kompetensi sosial (Menteri Pendidikan, 2007).

Kompetensi Kepribadian kepala sekolah yang peneliti temukan meliputi sebagai berikut: kepala sekolah memiliki akhlak mulia; amanah dalam mengemban tugas; disiplin, integritas yang tinggi; terbuka terhadap pembaharuan menerima kritik dan saran; keinginan yang kuat dalam pengembangan diri; memiliki minat dan bakat sebagai kepala sekolah. Kepala sekolah menjadi panutan bagi guru, siswa, dan seluruh warga sekolah sehingga kompetensi kepribadian ini sangat penting dimiliki kepala sekolah. Dokumentasi kepribadian kepala sekolah yang dapat membuat suasana sekolah lebih baik. 
Kompetensi kepribadian yang dimiliki kepala sekolah menurut Purwanto (2010: 55) meliputi: kepala sekolah yang jujur, adil, dan dapat dipercaya; rendah hati dan sederhana; percaya pada diri sendiri; sabar dan emosinya stabil; suka menolong; motivator; serta memiliki keahlian dalam jabatan sebagai kepala sekolah. Sedangkan berdasarkan penelitian Toharudin \& Ghufroni (2019) dijelaskan bahwa kepala sekolah memiliki kedisiplin yang tinggi dalam bekerja, bertanggung jawab, kekeluargaan, dan menerapkan budaya: senyum, sapa, salam bagi guru dan siswa.

Gaya kepemimpinan yang tepat dilakukan saat ini yaitu kepala sekolah yang memiliki visi misi ke depan, percaya diri, mampu mengkomunikasikan ide, dapat diteladani, mempunyai idealisme, inspirasi, kemampuan mempengaruhi dan mampu menghargai perbedaan untuk dirubah menjadi suatu kekuatan bersama (Ekosiswoyo, 2007). Berdasarkan berbagai kepribadian kepala sekolah yang telah dipaparkan, menjadi sebuah keistimewaan sebagai seorang pemimpin yang menjadi panutan untuk generasi penerus bangsa.

Kemampuan yang penting yang harus dimiliki kepala sekolah yaitu kemampuan manajerial, adapun kemampuan tersebut meliputi: kepala sekolah mampu memimpin sekolah; menyusun rencana program sekolah, kurikulum, serta berbagai kebijakan sekolah; mengelola guru, staf, peserta didik, serta seluruh warga sekolah; menjalin hubungan baik dengan wali murid, komite sekolah, serta masyarakat; mengelola sarana dan prasarana di sekolah; mengelola mengelola keuangan secara jujur, transparan, dan terpercaya; serta dapat mamanfaatkan kemajuan teknologi di sekolah.

Pada era revolusi industry 4.0 kepala sekolah dituntut untuk memiliki kompetensi kewirausahaan, sehingga dapat melahirkan berbagai kreativitas dan inovasi dari guru maupun siswa di sekolah. Berdasarkan hasil transkrip wawancara dengan narsumber, peneliti mendapatkan temuan bahwa kemampuan kewirausahaan sangat minim dilakukan di sekolah.

"Saya belum memiliki kewirausahaan di sekolah hal tersebut dikarenakan ratarata peserta didik berdasarkan dari latar belakang ekonomi yang kurang memadai, sehingga untuk menerapkan sekolah kewirausahaan cukup sulit dilakukan. Namun kedepannya saya akan membuat koperasi untuk siswa yang di dalamnya terdapat warung kejujuran". (Wawancara dengan narasumber $\mathrm{NH}$, pada tanggal 2 September 2019).

Berdasarkan kutipan tersebut, maka dapat disimpulkan bahwa kepala sekolah belum dapat mengembangkan kemampuan kewirausahaan di sekolahnya. Oleh karena itu, butuh bantuan dari berbagai pihak untuk dapat mengeksplor berbagai potensi yang dimiliki sekolah, kebanyakan kepala sekolah tidak mengetahui cara memulainya, tidak memiliki modal, kesulitan mencari sumber daya yang berkompetensi di bidang wirausaha. Pihak sekolah dapat menjalin bekerjasama dengan masyarakat sekitar yang memiliki Usaha Kecil dan Menengah (UKM) untuk berkolaborasi membentuk usaha di 
sekolah, sehingga diharapkan dengan kemampuan kewirausahaan yang dimiliki kepala sekolah dapat menjadikan sekolah lebih unggul dan mandiri.

Kompetensi kepala sekolah selanjutnya terkait dengan kompetensi untuk melaksanakan supervisi pendidikan di sekolah. Berdasarkan hasil wawancara dengan pengawas kepala sekolah tingkat Kabupaten Tangerang sebagai berikut:

"Sebagai pengawas saya selalu memberitahukan kepada kepala sekolah untuk dapat melakukan supervisi secara mandiri dan berkala, dalam rangka meningkatkan mutu pendidikan di sekolah. Selama ini para kepala sekolah beranggapan bahwa tugas supervisi merupakan tugas pengawas, padahal kegiatan supervisi merupakan bagian dari tugas kepala sekolah. Berbagai kemampuan yang harus dimiliki kepala sekolah perlu ditingkatkan sehingga mereka dapat meningkatkan kualitas kepemimpinannya." (Wawancara dengan narasumber $\mathrm{Uu}$, pada tanggal 18 September 2019).

Kepala sekolah memainkan peran penting dalam melakukan monitoring pendidikan, hal tersebut selaras dengan hasil penelitian yang dilakukan Fitrah (2017) kepala sekolah memiliki peran penting dalam melakukan berbagai upaya untuk meningkatkan kualitas pendidikan dengan melakukan monitoring, evaluasi terhadap program yang berorientasi pada visi misi sekolah.

Kompetensi terakhir yang harus dimiliki kepala sekolah yaitu kompetensi sosial yang dapat dilihat dari kerjasama antara kepala sekolah dengan masyarakat, sekolah dituntut untuk dapat berpartisipasi dalam kegiatan sosial dan memiliki kepekaan sosial di lingkungan sekitar.

Penelitian terkait kesiapan kepala sekolah dalam era revolusi industri 4.0 pernah dilakukan oleh Sugiarto (2019), hasil penelitian menunjukkan bahwa perlu adanya kesiapan profesionalisme kepala sekolah, kesiapan kepala sekolah dalam menghadapi tantangan, serta kesiapan dalam memberikan solusi terhadap masalah tantangan kepemimpinan kepala sekolah di era revolusi industry 4.0 .

Kepemimpinan yang ideal adalah kepemimpinan yang mengikuti tuntutan revolusi industri 4.0, pemimpin yang mengikuti perkembangan teknologi untuk dapat mempengaruhi, mendorong, membimbing, mengarahkan, dan menggerakkan orang lain untuk melaksanakan dan mengembangkan pendidikan dan pengajaran di era revolusi industi 4.0 (Wulandari, Febriansyah, Salwa, \& Sulaiman, 2019).

Berdasarkan temuan peneliti, masih banyak kepala sekolah yang belum memiliki kemampuan dalam perkembangan teknologi sehingga tidak bisa mengikuti perubahan zaman, ditambah lagi dengan sarana dan prasarana yang mendukung dalam pembelajaran berbasis teknologi yang masih minim ke Kabupaten Tangerang. Di Sekolah Dasar rata-rata hanya memiliki 35 komputer atau laptop dan tidak memiliki Laboratorium Komputer. Dokumentasi kepala sekolah yang sedang belajar menggunakan laptop, bahkan ada 
kepala sekolah yang baru menggunakannya.

Pentingnya bagi kepala sekolah untuk menguasai teknologi. Jangan sampai anak didik justru lebih pintar menggunakannya sehingga kontrol sosial terhadap anakanak tersebut kurang karena ketidakmampuan kepala sekolah maupun guru dalam teknologi. Selain itu, teknologi juga memudahkan guru dalam melakukan pengajaran menggunakan media pembelajaran dan memudahkan tenaga pendidik dalam mengerjakan administrasi sekolah. Teknologi dalam era revolusi industry 4.0 merupakan sebuah keharusan untuk dirasakan manfaatnya bagi dunia pendidikan dan menjadi sebuah tuntutan jika tidak ingin tergerus arus zaman.

Dalam Sosiologi Pendidikan maka kepala sekolah harus menjadi agen perubahan dimana kepala sekolah harus mengikuti perubahan yang ada. Namun pesatnya kemajuan teknologi tetap saja harus diimbangi dengan kualitas sumber daya manusianya. Tugas penting kepala sekolah dalam memberikan bekal untuk meningkatkan keterampilan abad 21 bagi guru dan siswa dengan memiliki keterampilan komunikasi, kreativitas, kolaborasi, dan kritis dalam memecahkan masalah. Selain itu, siswa diharapkan dapat mengimbangi diri dari dampak negatif kemajuan zaman dengan melakukan kegiatan yang positif.

Sosiologi melihat pendidikan sebagai miniatur dari masyarakat, oleh karena itu untuk menciptakan masyarakat yang berkualitas maka dimulai dari lembaga pendidikan. Menurut teori struktur fungsional masyarakat merupakan sistem sosial yang saling berkaitan terdapat sistem pendidikan, keluarga, masyarakat yang saling bersinergis mencapai keseimbangan dan keharmonisan (Setiadi \& Kolip, 2011).

Teori struktur fungsional memandang bahwa sekolah memiliki fungsi masingmasing sesuai dengan tugas dan tanggungjawabnya. Kepala sekolah dalam kacamata teori structural fungsional dapat menjalankan fungsinya dengan baik. Sehingga kepemimpinan kepala sekolah yang fungsional sangat menentukan kemajuan dari lembaga pendidikan yang dipimpinnya dan dapat memberikan manfaat bagi warga sekolah terutama bagi guru.

Hasil penelitian menunjukkan bahwa kepemimpinan kepala sekolah dapat mempengaruhi kinerja dan motivasi guru (Karweti, 2010; Sugiarto \& Mastikasari. 2018; Manik \& Bustomi, 2011; Setiyati, 2014; Baihaqi, 2015; Wahab, Mohd Fuad, Ismail, \& Majid, 2014), kepala sekolah dapat meningkatkan kedisipinan guru (Rusmawati, 2013), kepala sekolah berperan penting dalam meningkatkan profesionalisme guru (Lazwardi, 2016). Oleh karena itu, tidak heran jika tonggak dari kemajuan pendidikan di tangan kepemimpinan kepala sekolah.

Sebagai upaya untuk meningkatkan kompetensi yang dimiliki kepala sekolah, maka salah satunya dengan mengikuti kegiatan workshop tentang tugas dan kewajiban kepala sekolah yang dapat meningkatkan kualitas guru dan tenaga pendidik di sekolah yang dipimpinnya (Nursyifa, 2019). Selain itu, para kepala 
Jurnal Pendidikan Kewarganegaraan

Vol. 6 No. 2 September 2019
Journal of Civics and Education Studies p-ISSN 2302-0865 | e-ISSN 2621-346X sekolah juga dapat melanjutkan pendidikan yang lebih tinggi untuk memperbaharui keilmuan yang dimiliki, mengikuti berbagai pendidikan dan pelatihan, seminar, dan berbagai kegiatan yang mendukung untuk memberikan penguatan kepada kepala sekolah dalam kepemimpinannya.

\section{Kesimpulan}

Gaya kepemimpinan kepala sekolah mengalami tranformasi mengikuti perubahan, gaya kepemimpinan kepala sekolah yang lebih cocok saat ini yaitu dengan kepemimpinan demokratis yang dapat merangkul guru, siswa, komite sekolah, wali murid, maupun masyarakat. Dalam kajian sosiologi pendidikan maka sekolah harus menjalankan fungsinya dengan baik sehingga kepemimpinan kepala sekolah dapat menjadi kemajuan lembaga pendidikan yang dipimpin.

Menjadi kepala sekolah yang professional dituntut memiliki kompetensi kepribadian, manajerial, kewirausahaan, supervisi, dan kompetensi sosial. Keterampilan dalam menghadapi era revolusi industry 4.0 dapat dilihat dari kemampuan kepala sekolah dalam penggunaan teknologi dan kemampuan berwirausaha.

Upaya yang dilakukan kepala sekolah untuk meningkatkan kemampuan diri yaitu dengan melanjutkan pendidikan, mengikuti berbagai pelatihan, seminar, workshop, dan berbagai kegiatan yang mendukung. Perlu adanya kolaborasi dari berbagai pihak terutama pemangku kebijakan agar kepala sekolah dapat menjadi pemimpin yang professional dan berkualitas.

\section{Referensi}

Baihaqi, M. I. (2015). Pengaruh Gaya Kepemimpinan Kepala Sekolah dan Motivasi Kerja Terhadap Kinerja Guru. Kontruktivisme, 7(2), 97-106.

Damsar. (2012). Pengantar Sosiologi Pendidikan. Jakarta: Kencana.

Ekosiswoyo, R. (2007). Kepemimpinan kepala sekolah yang efektif kunci pencapaian kualitas pendidikan. Jurnal Ilmu Pendidikan, 14(2), 76-82.

Fitrah, M. (2017). Peran kepala sekolah dalam meningkatkan mutu pendidikan. Jurnal Penjamin Mutu, 3(1).

Haris, A. (2013). Modul Kepemimpinan Pendidikan. Surabaya: UIN Sunan Ampel.

Hidayat, R. (2014). Sosiologi Pendidikan Emile Dukheim (1 ed.). Jakarta: Grafindo.

Karweti, E. (2010). Pengaruh Kemampuan Manajerial Kepala Sekolah Dan Faktor yang Mempengaruhi Motivasi Kerja Terhadap Kinerja Guru. Jurnal Penelitian Pendidikan, 11(2), 77-89.

Kemendikbud. Undang-Undang Nomor 20 Tahun 2003 Tentang Sistem Pendidikan Nasional (2003). Diambil dari http://kelembagaan.ristekdikti.go.id/ wpcontent/uploads/2016/08/UU_no_20 _th_2003.pdf

Kemendikbud. (2018). Permendikbud Nomor 15 Tahun 2018.

Lazwardi, D. (2016). Peran Kepala Sekolah Dalam Meningkatkan 
Profesionalisme Guru. Jurnal Kependidikan Islam, 6(2), 139-157.

Manik, E., \& Bustomi, K. (2011). Pengaruh Kepemimpinan Kepala Sekolah, Budaya Organisasi, dan Motivasi Kerja Terhadap Kinerja Guru. Jurnal Ekonomi, Bisnis, dan Entrepreneurship, 5(2), 97-107.

Menteri Pendidikan. Peraturan Menteri Pendidikan Nasional Nomor 13 Tahun 2007 (2007).

Mukhlasin, A. (2019). Kepemimpinan Pendidikan di Era Revolusi Industri 4.0. Jurnal Tawadhu, 3(1), 674-692.

Mulyasa. (2007). Menjadi Kepala Sekolah Profesional. Bandung: Remaja Rosda karya.

Narwoko, J. D., \& Suyanto, B. (2014). Sosiologi Teks Pengantar dan Terapan. Jakarta: Prenada.

Nasution. (2009). Sosiologi Pendidikan. Jakarta: Bumi Aksara.

Nursyifa, A. (2019). Pembinaan Kepala Sekolah Dalam Upaya Meningkatkan Mutu Pendidikan. Jurnal Loyalitas Sosial, 1(1). Diambil dari http://openjournal.unpam.ac.id/index .php/JLS

Purwanto, N. (2010). Administrasi dan Supervisi Pendidikan. Bandung: Remaja Rosda Karya.

Rusmawati, V. (2013). Peran Kepemimpinan Kepala Sekolah Dalam Upaya Meningkatkan Disiplin Kerja Guru. E- JUrnal Administrasi Negara, $1(2), 395-409$.

Schwab, K. (2016). The Fourth Industrial Revolution. Switzerland: World Economic Forum.

Setiadi, E. M., \& Kolip, U. (2011). Pengantar Sosiologi Pemahaman Fakta dan Gejala Permasalahan Sosial Teori,
Aplikasi, dan Pemecahannya. Bandung: Kencana.

Setiyati, S. (2014). Pengaruh Kepemimpinan Kepala Sekolah, Motivasi Kerja, dan Budaya Sekolah. Jurnal Pendidikan Teknologi dan Kejuruan, $22(2)$, 200-207. https://doi.org/10.21831/jptk.v22i2.8 931

Silalahi, U. (n.d.). Metode Penelitian Sosial. Bandung: Refika Aditama.

Soekanto, S. (2010). Sosiologi Suatu Pengantar. Jakarta: Rajawali Pers.

Sugiarto, A., \& Mastikasari, K. (2018). Pengaruh Kepemimpinan

Transformasional Kepala Sekolah, Lingkungan Kerja, dan Budaya Sekolah Terhadap Kinerja Guru di SMA Kota Wates Dalam Menghadapi Revolusi Industri 4.0. In Prosiding Seminar Nasional FKIP. Yogyakarta: Universitas Sanata Dharma. Diambil dari http://usd.ac.id/snfkip2018

Sugiarto, S. (2019). Kesiapan Kepala Madrasah Aliyah Swasta Menyelenggarakan Pendidikan Pada Era Revolusi Industri 4.0. Jurnal Kepdndidikan, 4(1), 37-45.

Toharudin, M., \& Ghufroni. (2019). Leadership of The Headmaster in Managing Inclusive Elementary School in Brebes Regency. Educational Management, 8(2), 173-182.

Wahab, J. A., Mohd Fuad, C. F., Ismail, H., \& Majid, S. (2014). Headmasters' Transformational Leadership and Their Relationship with Teachers ' Job Satisfaction and Teachers , Commitments. International Education Studies, $7(13)$. https://doi.org/10.5539/ies.v7n13p40 
Jurnal Pendidikan Kewarganegaraan

Vol. 6 No. 2 September 2019

Wulandari, F., Febriansyah, D., Salwa, \& Sulaiman, R. M. (2019). Kepemimpinan Kepala Sekolah di Era Revolusi Industri 4.0 Dalam Meningkatkan Akreditasi Sekolah. In Prosiding Seminar Nasional Program Pascasarjana. Palembang: Universitas PGRI Palembang.
Journal of Civics and Education Studies p-ISSN 2302-0865 | e-ISSN 2621-346X

Yulizar, \& Farida. (2019). Kepemimpinan Kepala Sekolah di Era Disrupsi. In Prosiding Seminar Nasional Pendidikan (hal. 1060-1072). Palembang: Program Pascasarjana Universitas PGRI. 